"In Praise of Modern Economics"

by

David Colander

October 2008

MIDDLEBURY COLLEGE ECONOMICS DISCUSSION PAPER NO. 0814

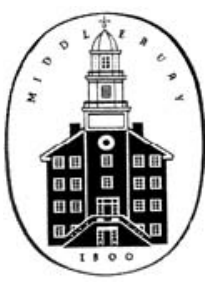

DEPARTMENT OF ECONOMICS

MIDDLEBURY COLLEGE

MIDDLEBURY, VERMONT 05753

http://www.middlebury.edu/ econ 


\section{In Praise of Modern Economics}

\section{David Colander, Middlebury College}

\section{(forthcoming in Eastern Economic Journal as part of a Symposium on Modern Economics)}

As a fellow critic of the economics profession, I find much to agree with in Barbara Bergmann's reflective review essay on the economics profession. (Bergmann, 200x) Both the economy and the economics profession need lots of work. But in a spirit of general irascibleness-a spirit that I suspect Barbara is one of the few who can fully appreciate--I will take a somewhat different position. Specifically, I will argue that Bergmann is far too hard on the profession in her description of what the profession has accomplished in the 35 years since the founding of the Eastern Economics Association.

Thirty-five years ago economics had serious problems: there was a limiting orthodoxy; students were cynical and treated economics like a game, and there was a notable lack of intellectual excitement within the field. Today, modern economics is a vibrant and advancing field that is intellectually alive and open to discovery. The orthodoxy has disappeared and graduate students are excited about what they are doing. Modern economics deserves praise, not nagging.

\section{Where Was the Profession 35 years ago?}

To understand my praise, you have to understand my sense of where the profession was 35 years ago. Thirty-five years ago, the profession was knee deep in orthodox neoclassical economics. (Some economists back then actually believed what the textbooks presented.) In theoretical micro, general equilibrium theory was the rage, and the best advice to students thinking of studying economics was to study Bourbakian math, specifically real analysis, and to prepare for a life of deductive proofs and lemmas. True, there was an empirical branch back then, but it was, rightly, not held in high regard. Much of that empirical work couldn't be replicated; it was added as an afterthought to a paper-Oh, I better add some empirical work to my paper to get it published. By many top economists of the time, empirical work was seen as an outlet for those who couldn't do theory.

Macroeconomic theory was similarly a mess. It was ideology embodied in models. Those mid 1970s were the time of the money matters wars. Somehow, Chicago always came to one conclusion, and Yale came to another, both using the same data set. It was a time when the IS/LM model ruled, and was pushed to extremes - in my graduate macro class I learned matrix IS/LM theory. Macro econometricians were busy developing ever larger models - the LINK model of the aggregate global economy was on the horizon--even though these econometric models had to be "fine tuned" (read "fudged") to come up with reasonable results, and those reasonable results were no better than backof-the-envelope calculations. 
Much of what was being done in macro at the time could have been justified as rough and ready engineering economics designed to give policy makers some sense of how to deal with something as complex as the macro economy, but it wasn't presented that way. It was presented as science. To me, and to most of my fellow graduate students, it was unbelievable science.

I fully recognize that the above characterization of economics 35 years ago is, in many ways, unfair. But it was the view that I, and many of my fellow students, had. Economics in the 1970s had serious problems; neither theory nor empirical work was on solid footing.

The one group that prospered in the 1970s was heterodox economists. The 1970s were a wonderful time to be a critic, since there were problems everywhere. There were so many things to criticize; you didn't know where to start. Back in those good old days, being heterodox had meaning and purpose. Indeed, the Eastern Economics Association took the lead in giving heterodox economics a voice: we were criticizing an embedded neoclassical and neoKeynesian orthodoxy and arguing that serious change was needed.

\section{Where Is Economics in 2009?}

Now fast forward to 2009, and it is apparent that the economics profession has changed, although not in the way that many of us critics wanted. Let's start by considering microeconomics. Today, the neoclassical economics orthodoxy is dead; it has been replaced by a modern economics plurodoxy--an eclectic mix of approaches that includes traditional neoclassical microeconomics, game theory, high-tech data mining, mechanism design, behavioral economics, experimental economics, ACE modeling, and neural economics, just to name a few of the many research programs. Whereas 35 years ago micro economics was characterized by the assumptions it made about individualsselfishness and rational choice-in 2009, it is characterized only by its modeling approach. What defines a micro economist in 2009 is his or her approach-a micro economist is someone who sees a problem, translates it into an incentive-based model, and takes the model to the data.

Modern microeconomic methods are fundamentally different from the economic methods of 35 years ago. Bourbakian mathematics is out, replaced by applied mathematics and statistics. Experimental economics has established itself as an important sub-field in economics, and economists are continually talking about "taking the model to the data”, finding a natural experiment, or designing a lab or field experiment to make their point. General equilibrium theory is now just a stepping stone--something students learn in the first few weeks of class, before they get on with more important issues. This change in focus can be seen in the private sector's demand for micro economists. Whereas 35 years ago, chairs of departments didn't have to worry about micro theorists being hired by business, today, they have to worry: there is a strong demand by business for microeconomists. For example, both Google and Yahoo have economics divisions, and mechanism design economists are in high demand by the private sector. 
Empirical analysis of economic models has also improved immensely; with the advances in computer technology, data analysis is much easier and much more convincing. Automated data analyses, such as found in PCGets, are on the horizon, with the promise that empirical work will get even better. While there are still debates about the empirical work's usefulness, the debates are not so one-sided against it as they were 35 years ago. The statistical analyses that economists do today are much more sophisticated and believable, in part because of better tools, and in part because much more care goes into doing the econometrics. In many ways the role of theory and empirical work has been reversed in the last 35 years. Today, researchers do the empirical work and add some theory to make it publishable.

Macroeconomics has also changed significantly. Thirty-five years ago, it was only us heterodox economists who said IS/LM was an unacceptable theoretical model of macro. Today, everyone agrees that it is. The money matters wars are over. The unbelievable macro econometric models of the past have been for the most part dumped; those that remain are seen as the rough and ready engineering models that they are. True, its replacement, the dynamic stochastic general equilibrium (DSGE) model is no improvement, but at least the DSGE model has logical foundations so you know what you are criticizing; that wasn't the case with IS/LM analysis.

In terms of macro practice, vector autoregression models have replaced structural models, and applied policy empirical macroeconomics has become more like "believable practical weather forecasting” than the deductive science it was earlier portrayed as being. In terms of macro policy, the best of the Keynesian insights remains - when a modern economy seems to be going into a recession, there are no calls to raise taxes, but rather recognition that deficits can be useful. Similarly, when the financial markets border on collapse, the existence of the DSGE model does not stop the Federal Reserve Bank from undertaking unorthodox policies that totally violate the precepts following from the DSGE model. It is clear that the DSGE model isn't relevant. This fast action by the Fed may well have prevented the collapse, at least temporarily, of the US economy. So, at least in macro policy, an era of reasonableness currently prevails.

Probably the most telling sign for me of the new openness of modern economics is the response I got from graduate students to the question of what the faculty were looking for from them (Colander, 2007). They told me that what the faculty was looking for was creativity, and that what they heard from their faculty for what to do in their research was to "tell them something they didn’t already know.” That, to me, is progress.

\section{The Role of Critics in Modern Economics}

The improvement of modern economics is hard on us critics. The low hanging fruit is gone. With the death of neoclassical orthodoxy, it is much harder to be a heterodox economist, because there is no orthodoxy for modern heterodoxy to draw life support from. There are, of course, still problems, and it is easy for us aging rebels to think that if only economists had done what we critics wanted them to do, all their problems would be solved. Alas, not. 
While it is true that Barbara Bergmann, me, or any other of the highly opinionated and outspoken critics of economics who have been involved in the Eastern Economics Association, could give 100 places where economics has gone wrong, and where if only they had followed our advice, the economy and the economics profession would have been better for it, that is not the entire story. If we are fully objective (which luckily none of us can be) we could also give 100 places where, had the profession had followed our advice, the economy and the economics profession would have been worse for it.

Consider Bergmann's push for more emphasis on an alternative brand of empiricism —an empiricism based in economists observing what real people do. It is something I've pushed for too, and I'm all for it as part of political economy-the practical, engineering part of economics designed to solve problems. I still believe that this approach offers what it probably the best way of devising reasonable policies and of creating usable macro models. But I hardly see that case-study observations as an appropriate analytic foundation for a microeconomic science. However, I do see what has developed-an empirical approach emphasizing natural and field experiments, built into a game theoretical analysis designed around empirically determined behavioral characteristics — as an appropriate analytic foundation. Had the profession listened to Bergmann and me, I suspect the current approach would not have developed. In the case study approach, how do you quantify, how do you generalize, how do you develop a solid analytic foundation?

My point is that it is not clear that the scientific aspect of the profession would have been better had it adopted the real-world empirical approach. After all, other social science fields, such as sociology, followed that case-study, observational, approach, and they have not done well in the competition for students and in the marketplace of ideas.

Luckily for us critics, the economy and the economics profession have not put our views to the test, which means that cognitive dissonance lets us focus on the 100 places where we may have been right, and to forget the 100 places where we may have been wrong, leaving us with a good image of ourselves. As I get older (oh, to think that I was around 35 years ago when the Eastern Economics Association was born out of the entrepreneurial efforts of Tejbhan Saini), that cognitively dissonant image of myself becomes more important as the mirror image of myself sags, even as I exercise more.

\section{A Final Comment}

While I praise modern economics, and Barbara Bergmann criticizes it, I suspect that our differences are not that great. Modern economics deserves both praise and criticism, just as kids do. Her essay highlights the half-empty nature of modern economics; mine highlights the half-full nature. We've come a long way, but we have a long way to go.

\section{References}

Bergmann. Barbara, 200x "The Economy and the Economics Profession - Both Need Work” Eastern Economic Journal. 
Colander, David. 2007. The Making of an Economist: Redux. Princeton University Press. Princeton. 